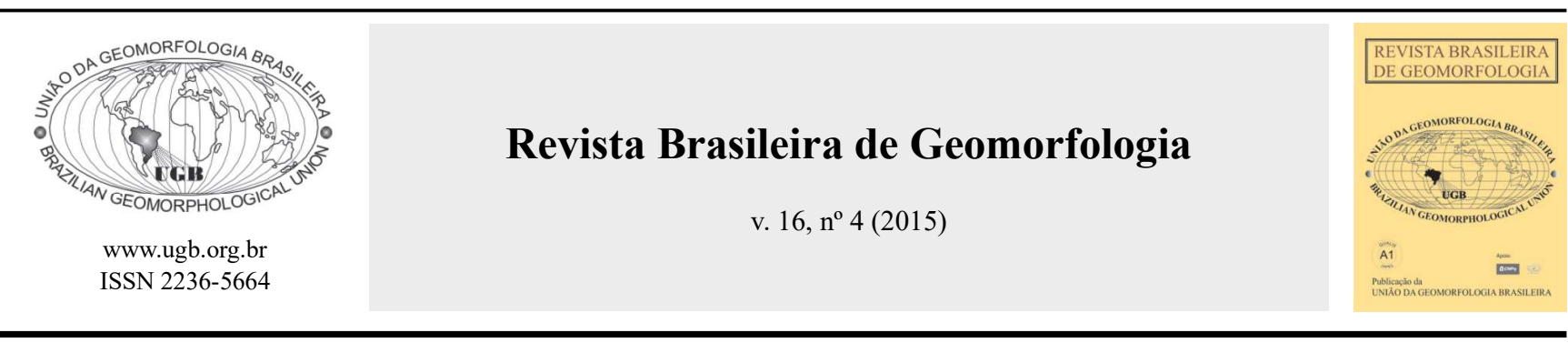

\title{
ANÁLISE GEOMORFOPEDOLÓGICA NA BORDA LESTE DA BACIA SEDIMENTAR DO PARANÁ, SUDESTE DO BRASIL
}

\section{GEOMORPHOPEDOLOGICAL ANALYSIS IN THE EASTERN EDGE OF THE PARANÁ SEDIMENTARY BASIN, SOUTHEASTERN BRAZIL}

\author{
Fernando Nadal Junqueira Villela \\ Departamento de Geografia, Universidade de São Paulo
} Av. Prof. Lineu Prestes 338, São Paulo, São Paulo, CEP 05508-900, Brasil

Email: geovillela@usp.br

Jurandyr Luciano Sanches Ross

Departamento de Geografia, Universidade de São Paulo

Av. Prof. Lineu Prestes 338, São Paulo, São Paulo, CEP 05508-900, Brasil

Email: juraross@usp.br

Sidneide Manfredini

Departamento de Geografia, Universidade de São Paulo

Av. Prof. Lineu Prestes 338, São Paulo, São Paulo, CEP 05508-900, Brasil

Email: sidmanfredini@gmail.com

\section{Informações sobre o Artigo}

Data de Recebimento:

$15 / 06 / 2015$

Data de Aprovação:

$06 / 10 / 2015$

\section{Palavras-chave:}

Geomorfopedologia. Relação Relevo-Rocha-Solo. Erosão

Geoquímica.

\section{Keywords:}

Geomorphopedology. ReliefRock-Soil Relationship. Geochemical Erosion.

\section{Resumo:}

Esta pesquisa demonstra relações de interdependência entre as formas de relevo, o substrato rochoso e os solos por meio de uma compartimentação geomorfopedológica em escala de detalhe (1:10.000). A área de estudo situase entre o embasamento cristalino pré-Cambriano do Planalto Atlântico e a cobertura sedimentar paleozoica na Depressão Periférica Paulista, região de Sorocaba/SP. Constatou-se que modelados de relevo aplainados, sustentados por litologias sedimentares, alternam-se com modelados mais dissecados, sustentados por litologias ígneas ou metamórficas, transição acompanhada por Latossolos Vermelhos nas áreas de topo e Cambissolos nos fundos de vale. Para o entendimento dessas associações, fizeram-se necessários levantamentos geológicos, geomorfológicos e pedológicos na busca da relação relevo-rochasolo. Os compartimentos geomorfopedológicos permitiram a compreensão de características funcionais do meio físico, tais como: condicionamento litoestrutural do modelado e do sistema de drenagem, conjugação dos processos exógenos, morfologia das vertentes e variações litológicas na formação dos solos e rebaixamento do relevo pela erosão geoquímica. 


\begin{abstract}
:
This research aimed to establish the interdependence relationship between landforms, bedrock and soil, through a geomorphopedological subdivision in detailed scale (1:10.000) of an area located between the Atlantic Plateau's Precambrian basement and the Paleozoic sedimentary cover of the Peripheral Depression of São Paulo, in the Sorocaba County, São Paulo State. Landforms in smooth hills sustained by sedimentary lithologies alternate with more dissected hills sustained by either igneous or metamorphic lithologies. Also Red Oxysols situated in flat top areas can change to Cambisols downstream. To understand these associations, geological, geomorphological and pedological survey of the area was needed to find out relief-rock-soil relationships. The geomorphological and geomorphopedological subdivisions allowed a better understanding of some functional characteristics of the physical environment as follows: the control of landforms and drainage system by lithostructure, the combination of exogenous processes, slope morphology and lithologic variations in forming soils and the possibility of relief being degraded by geochemical erosion.
\end{abstract}

\section{Introdução}

Dentre as inúmeras maneiras de estudar o modelado de relevo destacam-se aquelas calcadas na análise morfopedológica (CASTRO; SALOMÃO, 2000; TRICART; KILLIAN, 1979). Já na análise geomorfopedológica realizada neste trabalho, a geologia não é considerada somente substrato (litologia). Ela exerce um controle estrutural que irá condicionar a evolução do relevo e a pedogênese.

Por essa razão, o termo "Geomorfopedologia" indica as associações que enfatizam a necessidade de levantamento litológico e estrutural. Com isso, considera-se que abordagens integradas permitem maior conhecimento da evolução da paisagem, especialmente no meio tropical úmido, em que as superfícies podem ser exumadas ou enterradas, sobrepondo-se ou truncando-se, ao longo do tempo geológico, por processos mecânicos e/ou geoquímicos.

Em pesquisas realizadas na região de Sorocaba/ SP, foram verificados, por meio de análise da relação relevo-rocha-solo, os principais elementos que controlam a evolução geomorfológica e pedológica da área. Destacam-se fortes indícios de ação geoquímica na elaboração do modelado, uma vez que as áreas de topo encontram-se extensamente aplainadas e com solos desenvolvidos (VILLELA, 2011; VILLELA; ROSS; MANFREDINI, 2013).

Para King (1956), essa região sofre predomínio da denudação trabalhada sobre uma superfície morfogeneticamente associada à evolução da Depressão Periférica Paulista (DPP). Tal região corresponderia ao final do ciclo de erosão "Velhas" do Terciário Superior ou, como defendido por De Martonne (1943, 1944), ao truncamento das superfícies Neogênica e Pré-Permiana.
Como ocorre tipicamente na DPP, o relevo da área é constituído por colinas. Para Ab'Sáber (1972), essas colinas seriam herdadas da fisiografia terciária; nelas, fases úmidas dos aplainamentos encorpariam os mantos de decomposição. Nesse sentido, Thomas $(1979,1994 a)$ destaca ser o manto de intemperismo no Brasil extremamente espesso, indicando evolução morfogenética associada às alterações geoquímicas da superfície. Já Wambeke (1992) assinala que, na evolução de antigas superfícies geomórficas, há um caráter determinante da tropicalidade nas organizações pedológicas de topo: o desenvolvimento de Latossolos.

Essas observações podem ser relacionadas às superfícies geoquimicamente desenvolvidas em duplas superfícies de aplainamento dos modelos de etchplanação de Wayland (1933), aprimorados por Büdel (1982). Para este autor, a decomposição originaria duplas superfícies sobrepostas, caracterizando o processo responsável pela formação de etchplanos com superfície superior lavada (wash surface) e superfície inferior basal e intemperizada (basal weathering surface).

Por sua vez, Millot $(1977,1983)$ considera que a cobertura pedológica desempenha papel preponderante no desenvolvimento de superfícies aplainadas. Segundo o autor, essas resultam de climas pretéritos alternadamente secos e úmidos, cujo intemperismo acarreta alteração isovolumétrica, perda posterior de volume com desequilíbrio pedobioclimático da cobertura pedológica e transformação/redistribuição da matéria; consequentemente, há modificação na inclinação das vertentes com rebaixamento/aplainamento generalizado do relevo. Para ele, as transformações e as redistribuições dos materiais são inclusive marcadas por rupturas de declive atuais nas vertentes. 
No Brasil, trabalhos como os de Filizola (1993), Vitte (1998) e Coltrinari $(1975,2003,2011)$ apontaram novos modelos evolutivos da paisagem por meio da observação dos processos de alteração e pedogênese, indicando evolução geoquímica do modelado e condições tropicais úmidas ao menos desde o Terciário Superior. Os testemunhos desses processos seriam a presença regional de feições pseudocársticas; as interações endo e exogenéticas no modelado; o rebaixamento progressivo dos interflúvios, em razão do ajuste do nível de base regional; a exportação geoquímica; e a perda de material.

Ao serem encontradas rochas mais resistentes ao intemperismo em profundidade, é visível a redução da espessura dos perfis de alteração. Thomas (1994b) coloca que estes dependem da atuação não só do intemperismo, mas também da denudação. Segundo o autor, a diminuição da espessura de um perfil incorre na maior atuação desta, resultando em etchplanos. Quando a erosão atua na remoção dos mantos alterados nas zonas de topo, há truncamento das superfícies e exposições do pavimento rochoso mais resistente.

Nesse contexto, procurou-se compreender a dinâmica da relação relevo-rocha-solo na área de estudo. Para tanto, assume-se a existência de um controle estrutural exercido pelo substrato geológico e o rebaixamento do modelado por processos geoquímicos, visto a condição aplainada da superfície.

\section{2. Área de Estudo}

A área de estudo localiza-se no setor sudeste do Estado de São Paulo, no sudeste do Brasil, entre as latitudes $23^{\circ} 34^{\prime} 1^{\prime \prime}$ a $23^{\circ} 36^{\prime} 4^{\prime \prime} \mathrm{S}$ e as longitudes $47^{\circ} 32^{\prime} 3^{\prime \prime}$ a $47^{\circ} 29^{\prime} 2$ " W. Corresponde a um quadrante de $25 \mathrm{Km}^{2}$ e situa-se a $87 \mathrm{~km}$ da capital paulista, compreendendo parte dos municípios de Sorocaba, Salto de Pirapora e Votorantim, interligados pela Rodovia João Leme dos Santos, SP-264, conforme a Figura 1.

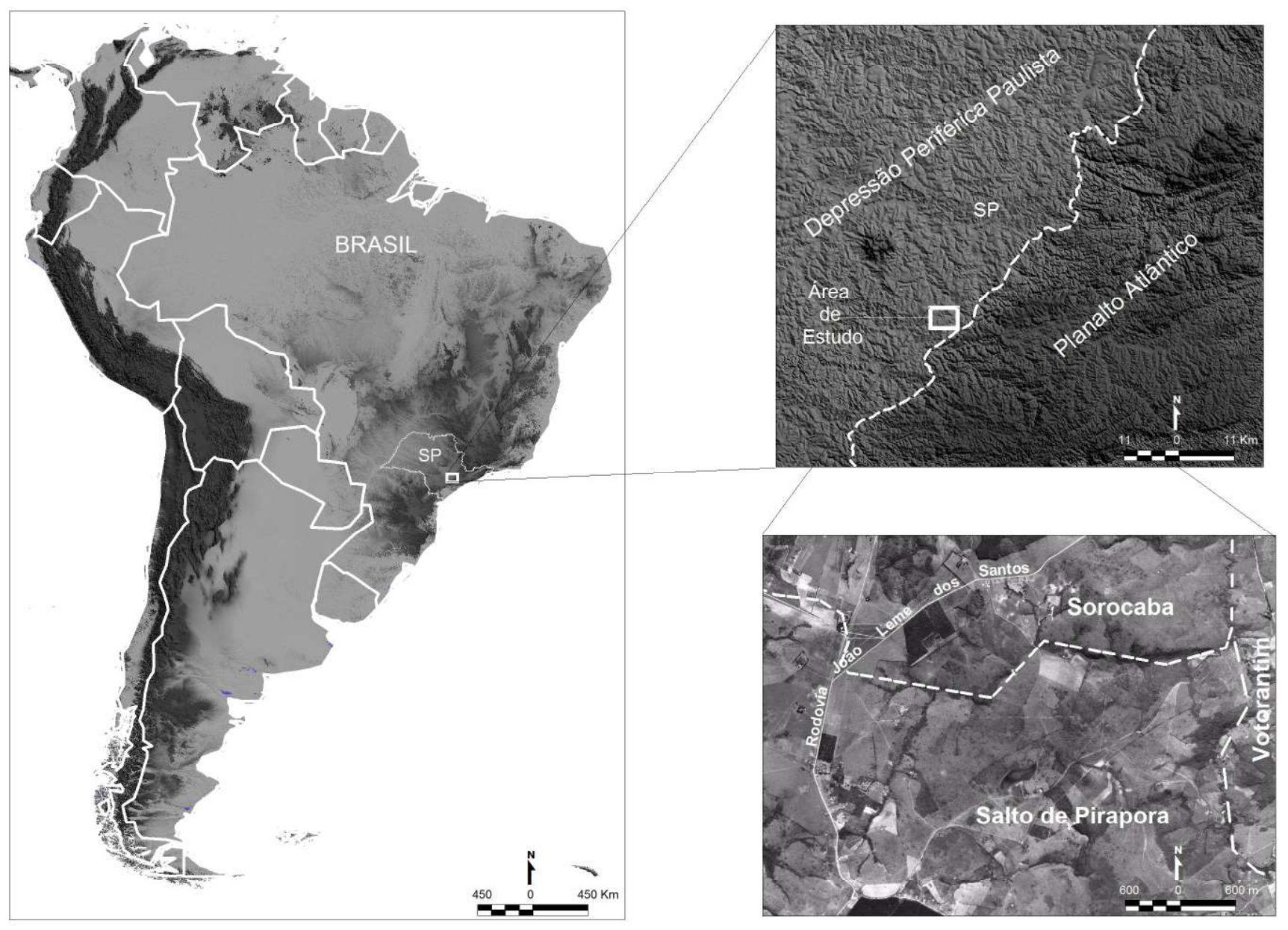

Figura 1 - Localização da área de estudo. Fonte: SRTM (2000); Ross e Moroz (1997). 
O quadrante contém cabeceiras de drenagem do Rio Tietê, correspondendo ao interflúvio que separa os rios Ipaneminha e Pirapora, ambos afluentes do Rio Sorocaba. O relevo da área varia de colinas a morrotes, com amplitudes topográficas de menos de 100 $\mathrm{m}$ e altimetrias de 595 a $716 \mathrm{~m}$. O Rio Ipaneminha é alimentado, em sua margem esquerda, pelos córregos Jucurupava, Barreiro e Utinga.

A área situa-se na Depressão Periférica Paulista, na transição do Planalto Atlântico para a Bacia Sedimentar do Paraná (ROSS; MOROZ, 1997). O relevo alterna-se entre interflúvios de topos mais planos, sustentados por litologias sedimentares paleozoicas (arenitos e siltitos), a formas mais rugosas, ligadas ao embasamento cristalino, como corpos graníticos e quartzíticos. Ademais, ocorrem Latossolos Vermelhos argilosos nas áreas de topo da maioria dos interflúvios e Cambissolos nos setores de vertente inferiores (VILLELA, 2011).

De acordo com dados do Instituto de Pesquisas Tecnológicas (2006), a vegetação, atualmente muito modificada, reflete a transição original de floresta ombrófila mista (porte arbóreo, montano e latifoliado) para mesófila (espécies lenhosas típicas de formações savânicas). O clima é do tipo tropical de altitude, no qual a pluviosidade concentra-se no verão e reduz-se consideravelmente no inverno, ocorrendo os menores volumes de chuva de junho a agosto. As temperaturas máximas se mantêm acima de $28^{\circ} \mathrm{C}$ no verão, e as mínimas se conservam abaixo dos $13^{\circ} \mathrm{C}$ no inverno, com chuvas anuais superando os $1300 \mathrm{~mm}$ (INMET, 2011).

\section{Materiais e Métodos}

Para a definição de unidades geomorfopedológicas utilizaram-se as abordagens de Tricart e Kilian (1979) somadas ao levantamento geológico (VILLELA, 2011; VILLELA; ROSS; MANFREDINI, 2013). Para a cartografia geomorfológica considerou-se a taxonomia dos fatos geomórficos de Ross (1991, 1992, 1994). Já para as compartimentações finais foram seguidas as orientações de Castro e Salomão (2000).

O mapeamento da relação relevo-rocha-solo foi apoiado em interpretação estereoscópica de fotografias aéreas pancromáticas na escala 1:25.000, levantamentos de campo e análises laboratoriais. A base cartográfica contou com cartas topográficas do Instituto
Geográfico e Cartográfico do Estado de São Paulo em escala 1:10.000 (IGC, 1979a,1979b, 1979c, 1979d); a essas foram ajustadas todas as outras delimitações, sendo elas: hipsometria, declividades, morfologia, pedologia e geologia, além das compartimentações geomorfológicas e geomorfopedológicas.

A fotointerpretação consistiu em operação prioritária para que fosse possível a realização de uma primeira compartimentação e escolha dos locais de coleta de amostras de solo. Nos levantamentos geológicos foram descritos afloramentos (tipo de rocha e orientação da foliação metamórfica e/ou estruturas sedimentares), os quais foram associados aos dados estratigráficos de um poço tubular aberto pela Jundsondas (2012).

No levantamento de solos foram realizadas descrições morfológicas da cobertura pedológica em trincheiras, de acordo com procedimentos estabelecidos por Santos et al. (2005), e amostragens obtidas por meio de tradagens (textura e cor). Os horizontes diagnósticos foram definidos segundo os critérios do SiBCS, Sistema Brasileiro de Classificação de Solos (EMBRAPA, 2009). Dez amostras de solo coletadas foram encaminhadas para análises laboratoriais, realizadas na ESALQ/USP, para a determinação da constituição granulométrica e da relação Silte/Argila, dos parâmetros químicos como fertilidade, da relação sílica-alumina (Ki) e sílica-sesquióxido $(\mathrm{Kr})$, e das características mineralógicas (constituintes mineralógicos da fração argila por difração de raios X).

\section{Resultados}

São apresentados a seguir os resultados dos levantamentos geológicos, geomorfológicos e pedológicos. Depois será feita a análise geomorfopedológica, que consiste em uma integração desses dados à discussão posterior.

\subsection{Geologia}

A geologia da área de estudo é composta por metassedimentos do Grupo São Roque (Neoproterozoico), biotita granitos do Maciço Sorocaba (Cambriano) e arenitos e siltitos do Grupo Tubarão (Neopaleozoico). Nas planícies fluviais ocorrem depósitos aluviais do Quaternário. 
A base da estratigrafia é representada por granitos porfiríticos do Maciço Sorocaba, os quais possuem granulação grosseira, com alta quantidade de quartzo, biotita e fenocristais de feldspato, correspondendo a batólito proveniente de eventos pós-orogênicos (GODOY, 1989). Há ocorrência de inúmeros afloramentos, geralmente sustentando os interflúvios mais íngremes e arredondados; estes podem se encontrar em estágio avançado de alteração.

Metassedimentos neoproterozoicos do Grupo São Roque (ALMEIDA et al., 1981) compõem metarritmitos, quartzitos e filitos, resultantes de metamorfismo regional de baixo grau (SILVA, 1997). Possuem estruturas verticais a subverticais e foliações que podem condicionar o sistema de drenagem, determinando muitas vezes a posição de lineamentos em planos ortogonais. Também podem ser observados carbonatos nesses metassedimentos, especialmente nos filitos.

Os afloramentos dos metassedimentos ocorrem mais associados às bases dos interflúvios, enquanto que os granitos afloram, em sua maioria, nas áreas de topo ou média vertente. Acima do embasamento cristalino são constatados sedimentos de origem glacial (INTERNATIONAL..., 1967), que caracterizam o topo da estratigrafia local e são compostos por arenitos e siltitos paleozoicos do Grupo Tubarão (ALMEIDA et al., 1981) e do Subgrupo Itararé (PÉREZ-VIEIRA, 2007).

\subsection{Geomorfologia}

Cinco tipos de formas de relevo foram descritos na área de estudo: topos convexos, área de divisores aplainados, setores de vertente amplos a dissecados e vales e planícies fluviais. $\mathrm{Na}$ área de divisores aplainados há depressão fechada interfluvial.

A partir dessas cinco formas de relevo foram definidos seis táxons, segundo o contexto geomorfológico da área, desde as grandes unidades do relevo até os processos pontuais: morfoestrutura, morfoescultura, formas do relevo, modelado (elementos morfológicos), intervalos altimétricos, declividades, solos, geologia e formas ligadas a processos de superfície (Figura 2).

Os topos planos ou convexos dominam a morfologia da paisagem. Os modelados mais íngremes são sustentados por metarritmitos, ao passo que as formas de relevo mais planas associam-se ao substrato sedimentar.

Os setores de maior altitude, acima de $680 \mathrm{~m}$, apresentam topos convexos localizados e vertentes adjacentes geralmente mais amplas (suavizadas), passando para níveis mais planos entre 680 e $645 \mathrm{~m}$ de altitude. Esses níveis de baixa declividade correspondem a divisores de água secundários de sub-bacias tributárias do Rio Ipaneminha. Em sentido jusante as declividades das vertentes podem aumentar e são acompanhadas por rupturas de declive e drenagens de segunda ordem nos intervalos altimétricos de 645 a $615 \mathrm{~m}$. Fica evidente o controle estrutural da drenagem em lineamentos perpendiculares. Também se evidenciam, de acordo com a direção da foliação metamórfica, algumas orientações dos interflúvios (setores de vertente íngremes e convexo-côncavos ou convexo-retilíneos). Abaixo dos $615 \mathrm{~m}$, nos setores das planícies fluviais, a inclinação diminui no nível de base local, o Rio Ipaneminha, atingindo $595 \mathrm{~m}$ de altitude.

Rupturas de declive nas vertentes e nos vales fluviais de drenagens intermitentes ou perenes se fazem, em sua maioria, por limites convexos. Vales associados aos lineamentos marcam as direções preferenciais da drenagem e os contatos do Maciço Sorocaba com outras litologias. A depressão interfluvial é circundada por uma ruptura de declive côncava, que contribui para o escoamento de água superficial em direção à sua superfície rebaixada.

\subsection{Pedologia}

Os solos da área de estudo são compostos por Latossolos, Cambissolos e Gleissolos. Nos níveis em que ocorrem topos convexos e divisores aplainados, entre 715 e 650 m, existem Latossolos Vermelhos de textura argilosa, com horizonte A moderado e horizonte B latossólico (Bw), conforme exposto na Tabela 1. A estrutura desses Latossolos é microagregada, com poros pequenos e grandes de frequência abundante; há também uma porosidade fissural, em razão das variações de umectação e dessecação do solo.

Nos setores de vertente amplos entre 650 e 630 $\mathrm{m}$ ocorrem Cambissolos argilosos, sujeitos ao espessamento do horizonte $B$, com sua estrutura evoluindo para organização latossólica. Esses solos se dispõem em blocos subangulares fracos, desfazendo-se em estrutura granular, com porosidade média e frequência comum.

Abaixo de $630 \mathrm{~m}$ de altitude existem Cambissolos com horizontes $\mathrm{Bi}$ em setores de declives mais acentuados. A estrutura organiza-se também em blocos subangulares que desfazem-se em granular, com porosidade pequena e pouca frequência. Nas planícies fluviais restritas e na depressão fechada interfluvial encontram-se solos hidromórficos de textura argilosa (Gleissolos). 
Villela F. N. J. et al.

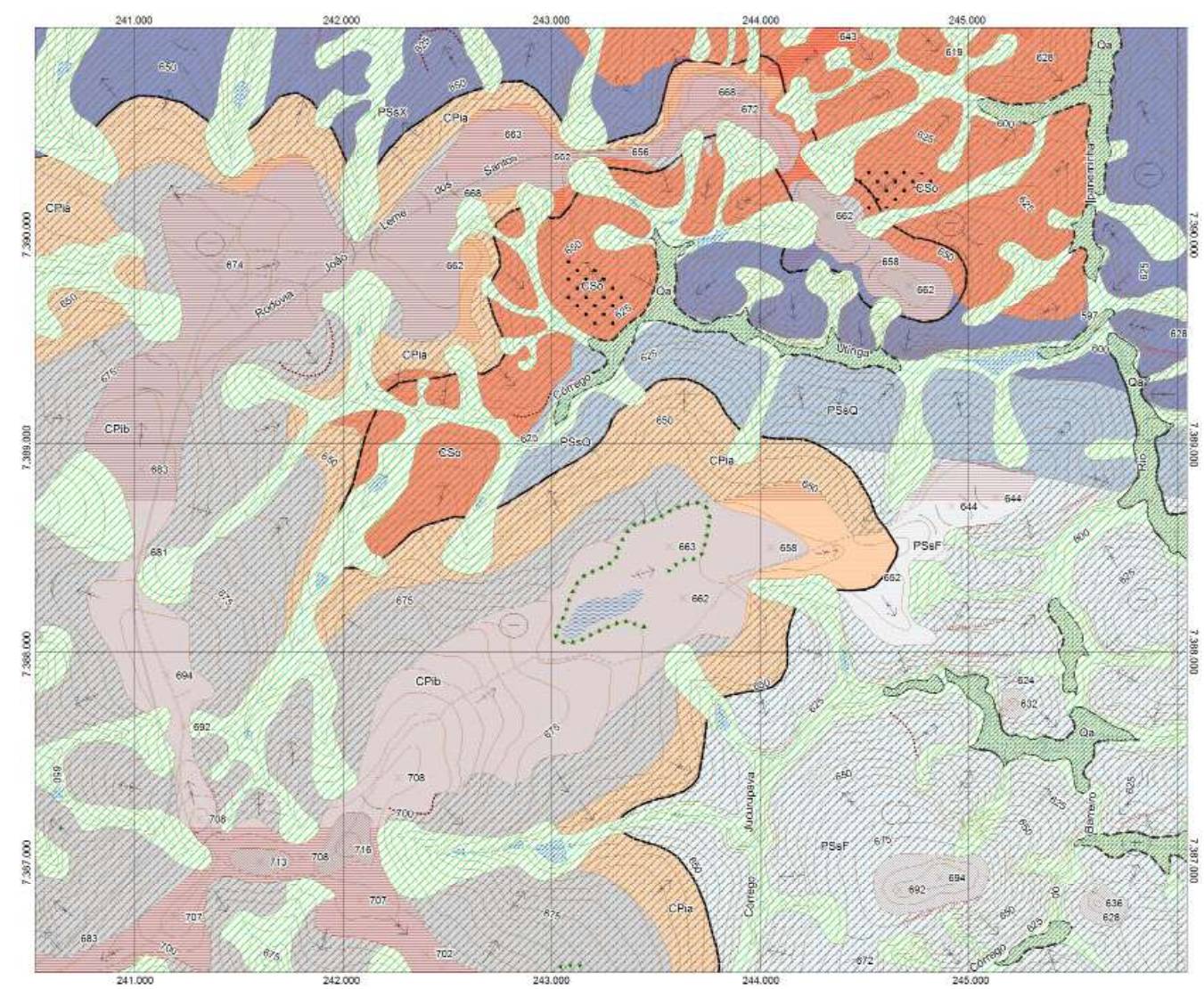

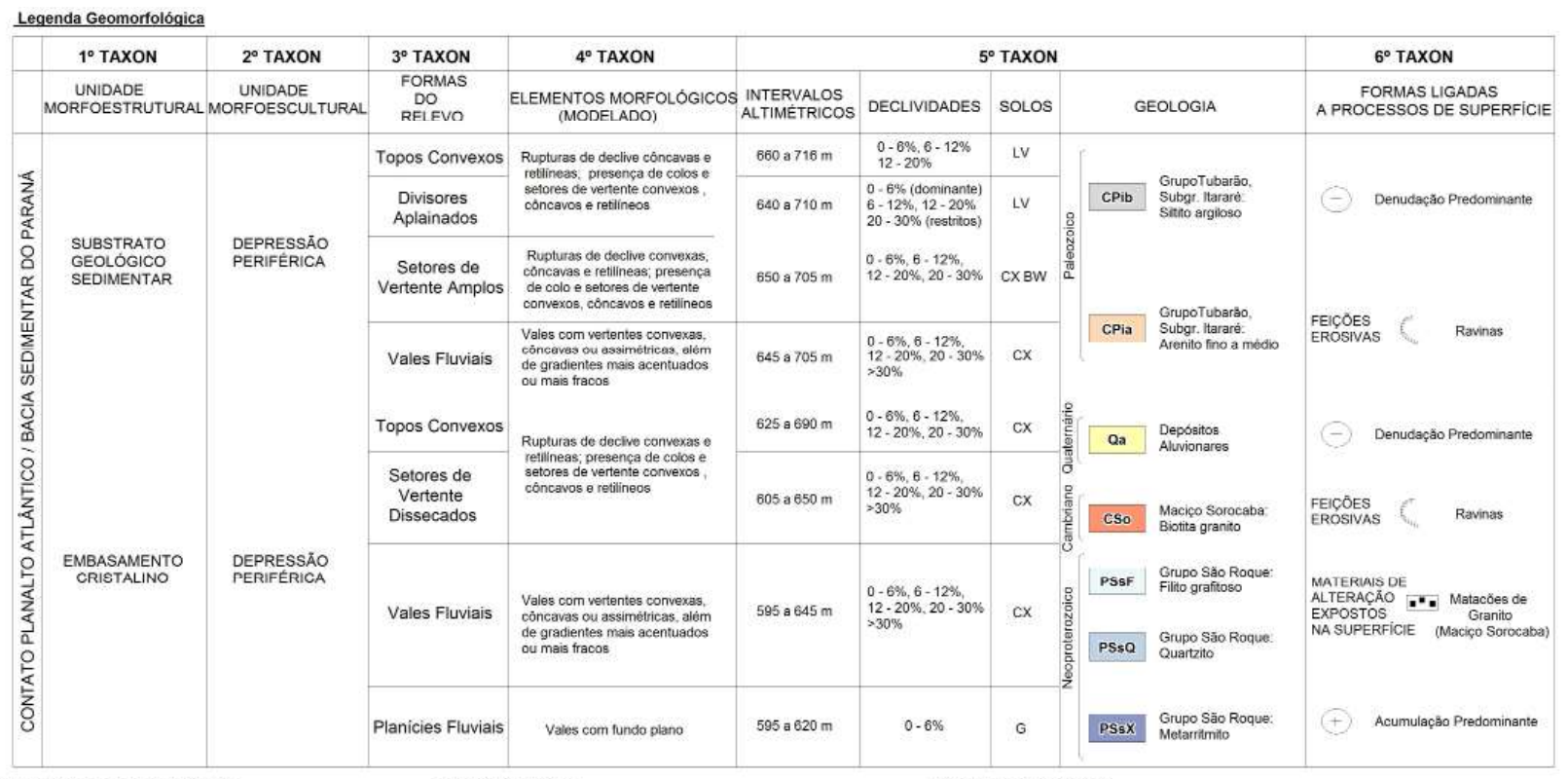

\begin{tabular}{|c|c|c|c|c|c|}
\hline \multicolumn{3}{|c|}{ CONVENÇÖES CARTOGRÄFICAS } & \multirow{3}{*}{$\begin{array}{l}\text { Formas do Relevo } \\
\text { TOPOS CONVXOS } \\
\text { ONISORES APLAINADOS } \\
\text { SETORES DE VERTENTE AMPLOS A DISSECADOS }\end{array}$} & \multicolumn{2}{|c|}{ Elementos Morfológicos } \\
\hline ESTRAD & & ALTIMETRIA & & TIPO & SIMBOLO \\
\hline 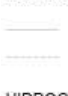 & $\begin{array}{l}\text { Pavimentada } \\
\text { Sem Pavimentaç̧a }\end{array}$ & $\begin{array}{ll}644 & \text { Cotas } \\
& \text { Curvas de Nivel }\end{array}$ & & $\begin{array}{l}\text { RUPTURAS } \\
\text { DE } \\
\text { DECLUE }\end{array}$ & $\begin{array}{l}\because \text { Ruptura Convexa } \\
\vdots \quad \text { Ruptura Concava }\end{array}$ \\
\hline COAOCOA & $\begin{array}{l}\text { Curso D'Agua Perene } \\
\text { Curso D'Agua Intermitente }\end{array}$ & LIMITES & Solos & & Ruptura Retilinea \\
\hline \& & $\begin{array}{l}\text { Represa } \\
\text { Depresssä Interfhuvial }\end{array}$ & $\sim$ Limite Sedimentart & $\begin{array}{l}\text { LV - LATOSSOLOS VERMELHOS } \\
\text { CX } w \text {-CAMBISSOLOS EVOLUINDO PARA ORG. BW } \\
\text { CX-CAMBISSOLOS } \\
\text { G- GLEISSOLOS }\end{array}$ & $\begin{array}{l}\text { EM DIVISORES } \\
\text { TOPOGRAFICOS }\end{array}$ & 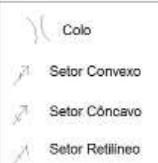 \\
\hline
\end{tabular}

Figura 2 - Mapa geomorfológico. Fonte: elaboração dos autores. 
Análises de laboratório demonstraram que os Latossolos Vermelhos são solos maduros, indicando processos de monossialitização e formação de caulinita (Tabela 1). Um processo de hidrólise mais avançada também é notado a partir da acumulação de gibbsita no horizonte Bw. Já nos Cambissolos evoluindo para organização de horizonte Bw predominam processos de monossialitização, enquanto nos Cambissolos as análises de laboratório indicam haver mistura de minerais de argila 1:1 e 2:1. O grau de intemperismo das amostras de solo pode ser evidenciado pelas relações molares Ki e $\mathrm{Kr}$ e relação Silte/Argila.

Conforme a Tabela 1, o ponto 1 corresponde ao Latossolo Vermelho, apresentando alto grau de intemperismo. A mineralogia da fração argila aponta a presença de caulinita e uma fração menor de gibbsita, além de uma quantidade significativa de quartzo. Já nos pontos 2, 4, 5, 6 e 10, cuja classificação é de Cambissolo evoluindo para organização de horizonte $\mathrm{Bw}$, ocorrem texturas argilosas a médio-argilosas, com intemperismo avançado para Cambissolos. A mineralogia também indica a predominância de caulinita e traços de gibbsita, e a ocorrência de argilo-minerais 2:1 e quartzo.

Os pontos 3, 8 e 9 acusam características de Cambissolos típicos, em razão da textura argilosa e do grau de intemperismo intermediário. Apesar da presença de caulinita e gibbsita na mineralogia, são notadas maiores quantidades de argilo-minerais $2: 1$ e quartzo nestas amostras em relação às demais. Já o ponto 7 , associado ao Gleissolo, apresenta manchas de hidromorfia e textura argilosa, com grau de intemperismo avançado e mineralogia com predominância de caulinita.

\subsection{Geomorfopedologia}

A partir da interpretação dos mapeamentos elaborados e das consequentes intersecções com os dados de gabinete, laboratório e campo, foi possível identificar quatro unidades geomorfopedológicas na área de estudo. São demonstradas na Figura 3 suas transições quanto às formas de relevo, aos intervalos altimétricos, às declividades, ao substrato geológico e aos solos, sendo também apresentados perfis esquemáticos.

Tabela 1: Dados de amostras de solo coletadas para classificação.

\begin{tabular}{|c|c|c|c|c|c|c|c|c|c|c|c|}
\hline Ponto & Hor. & $\begin{array}{l}\text { Prof. } \\
(\mathrm{cm})\end{array}$ & $\begin{array}{c}\text { Posição } \\
\text { na Vertente }\end{array}$ & $\begin{array}{c}\text { Material } \\
\text { de } \\
\text { Origem }\end{array}$ & Cor & $\begin{array}{c}\text { Classe } \\
\text { Textural }\end{array}$ & $\begin{array}{c}\text { Relação } \\
\text { Silte/ } \\
\text { Argila }\end{array}$ & $\mathbf{K i}$ & $\mathbf{K r}$ & Mineralogia & Ordem \\
\hline 1 & $\mathrm{Bw}$ & 120 & Topo & Siltito & 10R 4/6 (v) & $\mathrm{m}-\arg$ & 0,18 & 1,52 & 1,24 & Caul., Gibbs., Quartz. (p) & LV \\
\hline 2 & $\mathrm{Bi}$ & 85 & Terço Médio & Arenito & $2.5 Y R 4 / 8(v)$ & arg & 0,32 & 1,55 & 1,35 & Caul., Gibbs., Quartz. (p) & $\mathrm{CX} \mathrm{Bw}$ \\
\hline 3 & $\mathrm{Bi}$ & 60 & $\begin{array}{l}\text { Terço } \\
\text { Inferior }\end{array}$ & Quartzito & 5YR 5/6 (v-a) & $\arg$ & 0,25 & 2,33 & 1,74 & $\begin{array}{l}\text { Caul., Gibbs., A-m 2:1, } \\
\text { Quartz. (p) }\end{array}$ & $\mathrm{CX}$ \\
\hline 4 & $\mathrm{Bi}$ & 90 & Topo & Siltito & 5YR 5/6 (v-a) & $\mathrm{m}-\arg$ & 0,21 & 2,16 & 1,72 & $\begin{array}{l}\text { Caul., Gibbs., A-m 2:1, } \\
\text { Quartz. (p) }\end{array}$ & $\mathrm{CX} \mathrm{Bw}$ \\
\hline 5 & $\mathrm{Bi}$ & 65 & $\begin{array}{c}\text { Terço } \\
\text { Superior }\end{array}$ & Granito & 5YR 3/4 (b-av-esc.) & $\arg$ & 0,25 & 1,51 & 1,31 & Caul., Gibbs., Quartz. (p) & $\mathrm{CX} \mathrm{Bw}$ \\
\hline 6 & $\mathrm{Bi}$ & 65 & Terço Médio & Granito & $5 Y R 4 / 6(v-a)$ & arg & 0,26 & 1,25 & 1,07 & Caul., Gibbs., Quartz. (p) & $\mathrm{CX} \mathrm{Bw}$ \\
\hline 7 & $\mathrm{Bg}$ & 95 & $\begin{array}{l}\text { Terço } \\
\text { Inferior }\end{array}$ & $\begin{array}{c}\text { Depósitos } \\
\text { Aluvionares }\end{array}$ & $\begin{array}{l}7.5 \mathrm{YR} \quad 5 / 6 \quad \text { (b-forte } \quad \mathrm{c} / \\
\text { manchas de hidromorfia) }\end{array}$ & $\arg$ & 0,17 & 1,64 & 1,38 & Caul., Gibbs., Quartz. (p) & G \\
\hline 8 & $\mathrm{Bi}$ & 75 & Topo & Filito & 5YR 6/4 (b-av-claro) & $\arg$ & 0,73 & 2,01 & 1,39 & $\begin{array}{l}\text { Caul., A-m 2:1, Quartz. } \\
\text { (g), Gibbs., Feldsp. }\end{array}$ & $\mathrm{CX}$ \\
\hline 9 & $\mathrm{Bi}$ & 80 & Terço Médio & Filito & 10YR 5/3 (bruno) & $\arg$ & 0,62 & 2,23 & 1,68 & $\begin{array}{l}\text { Caul., A-m 2:1, Quartz. } \\
\text { (g), Gibbs. }\end{array}$ & $\mathrm{CX}$ \\
\hline 10 & $\mathrm{Bi}$ & 55 & Terço Médio & Quartzito & 5YR 5/6 (v-a) & md-arg & 0,13 & 2,01 & 1,73 & $\begin{array}{l}\text { Caul., Gibbs., A-m 2:1, } \\
\text { Quartz. (p) }\end{array}$ & $\mathrm{CX} \mathrm{Bw}$ \\
\hline
\end{tabular}

Fonte: $E S A L Q / U S P$.

Legenda: $B w=B$ latossólico; $B i=B$ incipiente; $B g=B$ glei; $v=$ vermelho; $v$ - $a=$ vermelho-amarelado; $b$-av-esc. $=$ bruno-avermelhadoescuro; $b$-forte = bruno forte; $b$-av-claro = bruno-avermelhado-claro; $m$-arg = muito argilosa; $\arg =$ argilosa; $m$ d-arg = médio-argilosa; Caul.$=$ Caulinita $;$ Gibbs. $=$ Gibbsita $;$ A-m 2:1 = Argilo-minerais 2:1; Feldsp. =Feldspato; Quartz. $($ p) = pequena quantidade de Quartzo; Quartz. $(g)$ = grande quantidade de Quartzo; $L V=$ Latossolo Vermelho; $C X$ Bw = Cambissolo evoluindo para organização de horizonte B latossólico; $C X=$ Cambissolo; $G=$ Gleissolo. 
Villela F. N. J. et al.

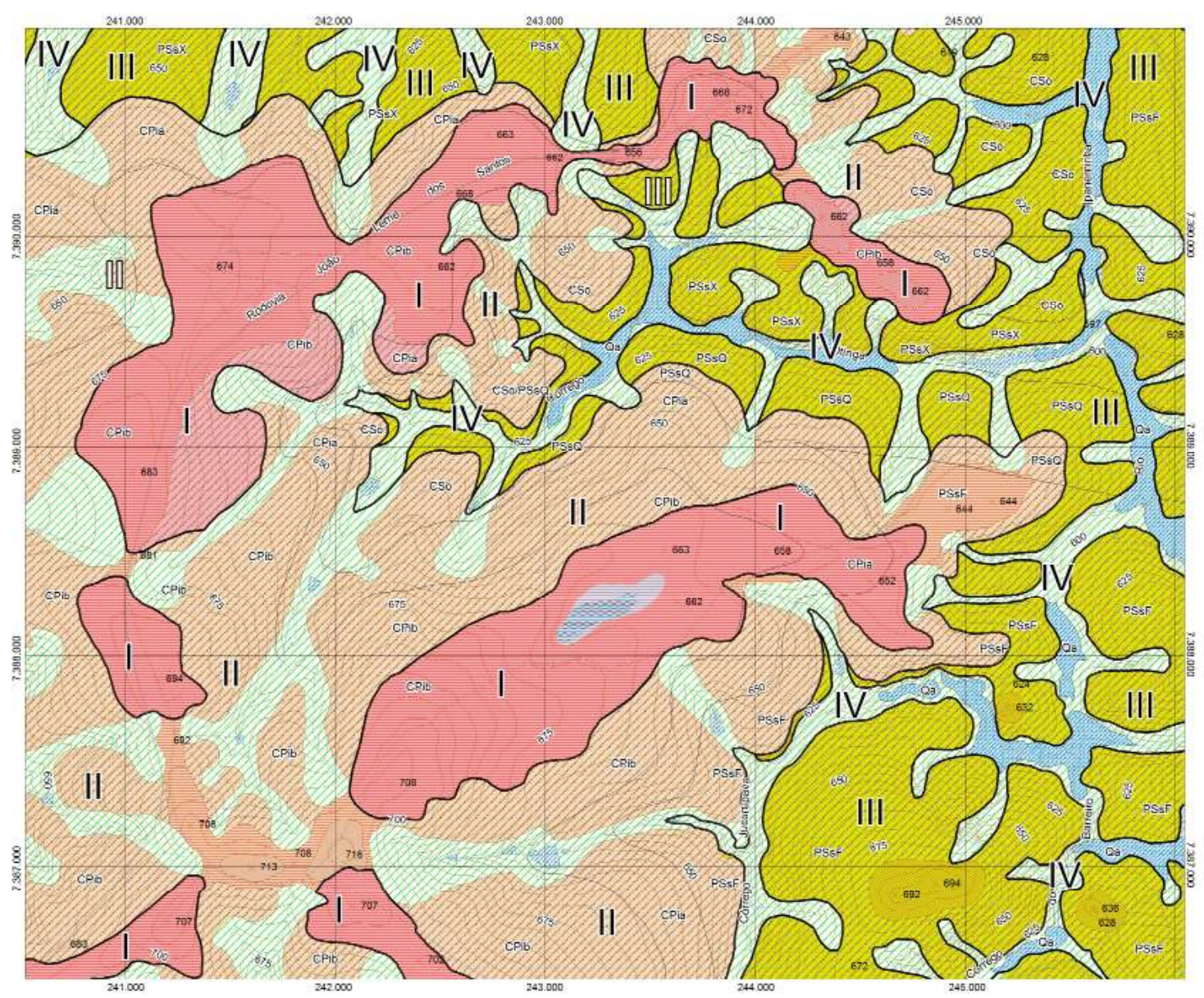

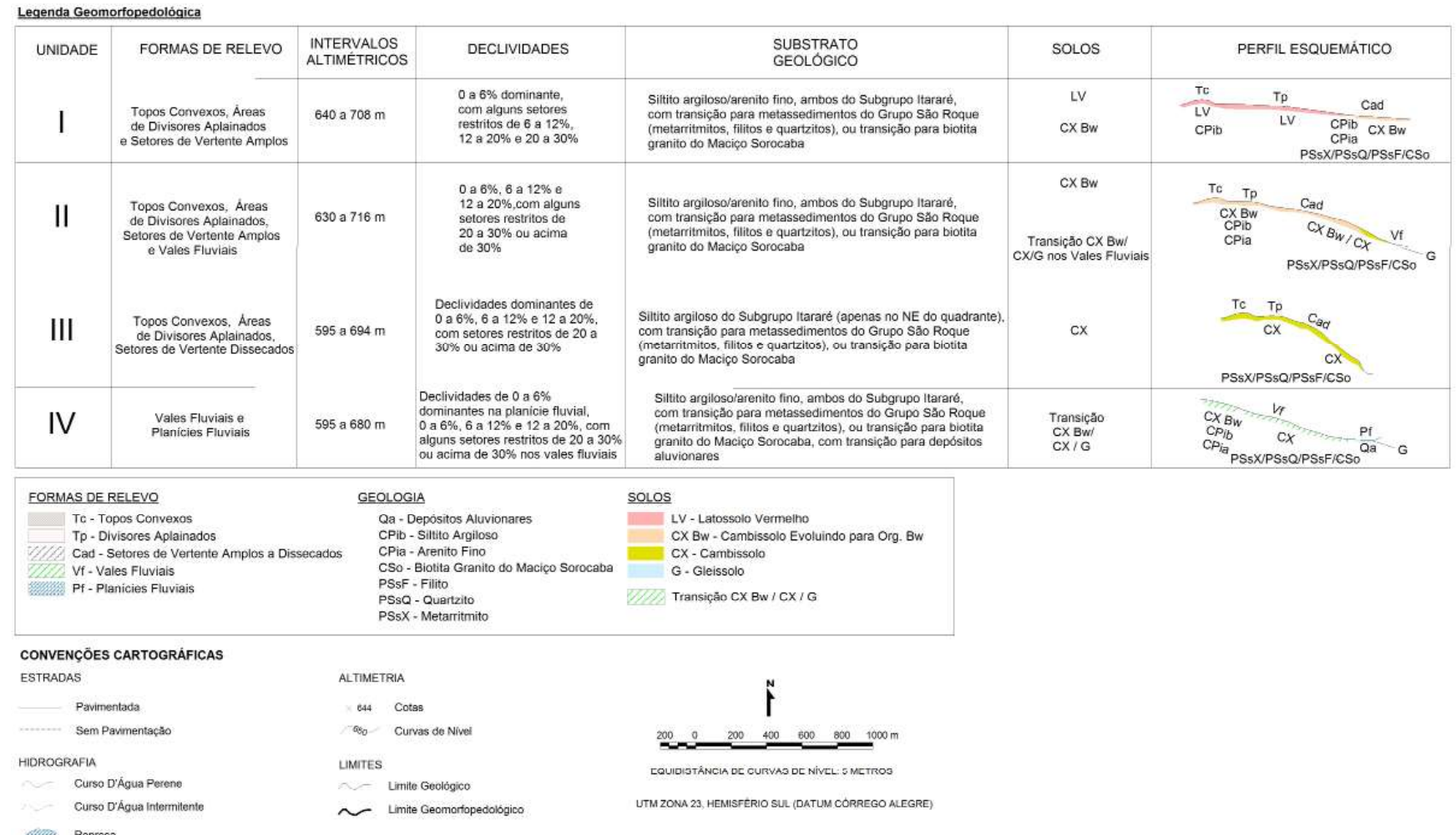

Figura 3 - Mapa geomorfopedológico. Fonte: Elaborado pelos autores. 


\section{Discussão}

Em seguida são apresentadas as discussões do contexto geológico-geomorfológico da área de estudo, dos processos de intemperismo e pedogênese e da geomorfopedologia. Esses três aspectos são considerados a partir da interação dos solos com as formas de relevo e o substrato geológico.

\section{1 Síntese do Contexto Geológico-Geomorfológico}

O contato entre a cobertura sedimentar e o embasamento cristalino é análogo à superfície fóssil Pré-Permiana e à superfície Neogênica, apontadas por De Martonne (1943). Há uma superfície enterrada, que representa assoalho mais antigo, e uma superfície mais recente, trabalhada sobre rochas mais tenras e menos espessas. A superfície mais antiga é em parte exumada, em razão da denudação, expondo o substrato cristalino em terrenos mais rugosos. Por outro lado, a superfície mais recente sofre contínua erosão, truncando com a primeira em terrenos mais aplainados, sustentados pelo substrato sedimentar (Figura 4).

As exposições na superfície do batólito do Maciço Sorocaba (base da coluna estratigráfica) permitem afirmar que há o truncamento de uma antiga superfície enterrada com uma superfície sobreposta mais recente e erodida (sedimentos paleozoicos no topo da coluna estratigráfica). Essas compõem o cenário de duplas superfícies de aplainamento, tal qual indicado por Büdel (1982) e Millot (1977, 1983).
Portanto, as formas de relevo aplainadas sustentadas pela litologia sedimentar e recobertas por solos argilosos espessos podem corresponder a uma superfície de lavagem em franco processo de maturação geoquímica (monossialitização). Por outro lado, a exposição das formas de relevo mais rugosas, sustentadas por granitos que caracterizam o embasamento, podem indicar uma antiga e exumada superfície basal de intemperismo.

\subsection{Intemperismo e Pedogênese}

A pedogênese é mais avançada nas formas de relevo planas e amplas, onde se notam solos mais desenvolvidos nas alterações da litologia sedimentar. Em contraposição, pedogênese mais incipiente é observada nos setores das vertentes de maior declividade, nas áreas de litologia ígnea e/ou metamórfica. Desse modo, os solos variam de acordo com o substrato e possuem pedogênese mais avançada ou não também segundo o modelado.

Nos divisores aplainados e nos setores de vertente amplos há hidrólise parcial (monossialitização, segundo o domínio gibbsítico dos resultados da relação Ki e os picos cauliníticos na mineralogia), ocorrendo Latossolos Vermelhos e Cambissolos evoluindo para a organização de horizonte B latossólico. Ao observar-se a ocorrência de superfícies mais inclinadas que acompanham a mudança do substrato sem que haja mudanças bruscas no relevo, verifica-se transição de solos e hidrólise menos intensa (monossialitização

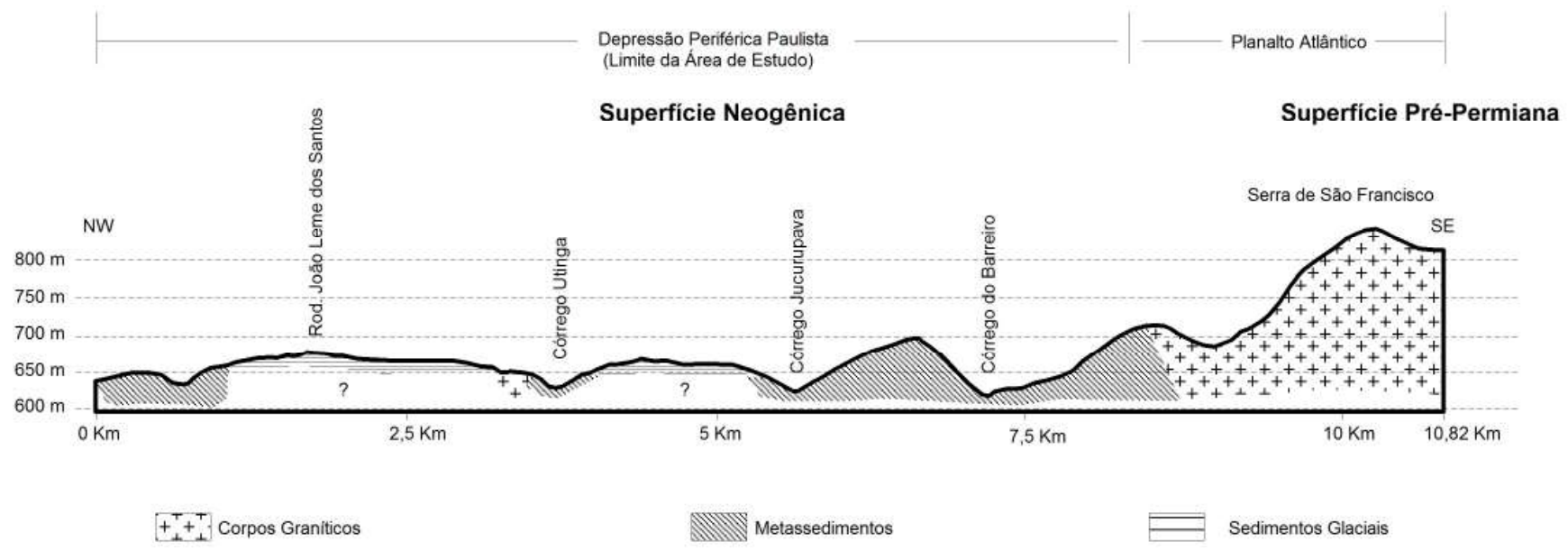

Figura 4 - Perfil geológico-topográfico da Serra de São Francisco (limite cristalino do Planalto Atlântico) para a Depressão Periférica Paulista. Fonte: SRTM (2000). 
à bissialitização, segundo o domínio caulinítico dos resultados da relação $\mathrm{Ki}$ e as evidências de argilo-minerais 2:1 na mineralogia).

Embora as análises de campo e laboratório apontem condições de intemperismo avançado em alguns casos, isso não necessariamente implica em processos de alitização. Na mineralogia se verificam picos bem cristalizados de caulinita, em contraposição aos picos menos definidos de gibbsita, demonstrando haver processo predominante de monossialitização ou bissialitização quando há aparecimento de argilo-minerais $2: 1$. O domínio gibbsítico dado pela relação $\mathrm{Ki}<1,8$ em alguns resultados apenas indica intemperismo local avançado, sendo os dados insuficientes para afirmar a ocorrência de hidrólise total e/ou atuação de climas pretéritos predominantemente úmidos nessas superfícies.

\subsection{Interação dos Solos com as Formas de Relevo e o Substrato Geológico}

As transições predominantes das unidades geomorfopedológicas (Figura 3) do topo ao fundo de vale indicam:

- Unidade Geomorfopedológica I - sequência de solos com horizontes $\mathrm{LV}-\mathrm{Cx} \mathrm{Bw}-\mathrm{Cx}-\mathrm{G}$ marcada pela passagem da área de divisores aplainados para setores de vertente amplos e depois para vales e/ ou planícies fluviais, sustentados respectivamente pelo material sedimentar síltico-argiloso e pelo substrato cristalino (ígneo ou metamórfico), correspondendo ao perfil A-B (Figura 5);

- Unidade Geomorfopedológica II - sequência de solos com horizontes $\mathrm{Cx}$ Bw-Cx-G marcada pela passagem de topos convexos para setores de vertente dissecados e posteriormente para vales e/ou planícies fluviais, ambos sustentados pelo substrato ígneo, correspondendo ao perfil C-D (Figura 6);

- Unidade Geomorfopedológica III - sequência de solos com horizontes $\mathrm{Cx}-\mathrm{G}$ marcada pela passagem de setores de vertente dissecados para vales e/ou planícies fluviais, sustentados pelo substrato metamórfico, correspondendo ao perfil E-F (Figura 7);

- Unidade Geomorfopedológica IV - sequência de solos com horizontes $\mathrm{Cx} \mathrm{Bw}-\mathrm{Cx}-\mathrm{G}$ caracterizada pela passagem de vales fluviais para planícies fluviais, com transições morfológicas e litológicas variadas (não representada em perfil).

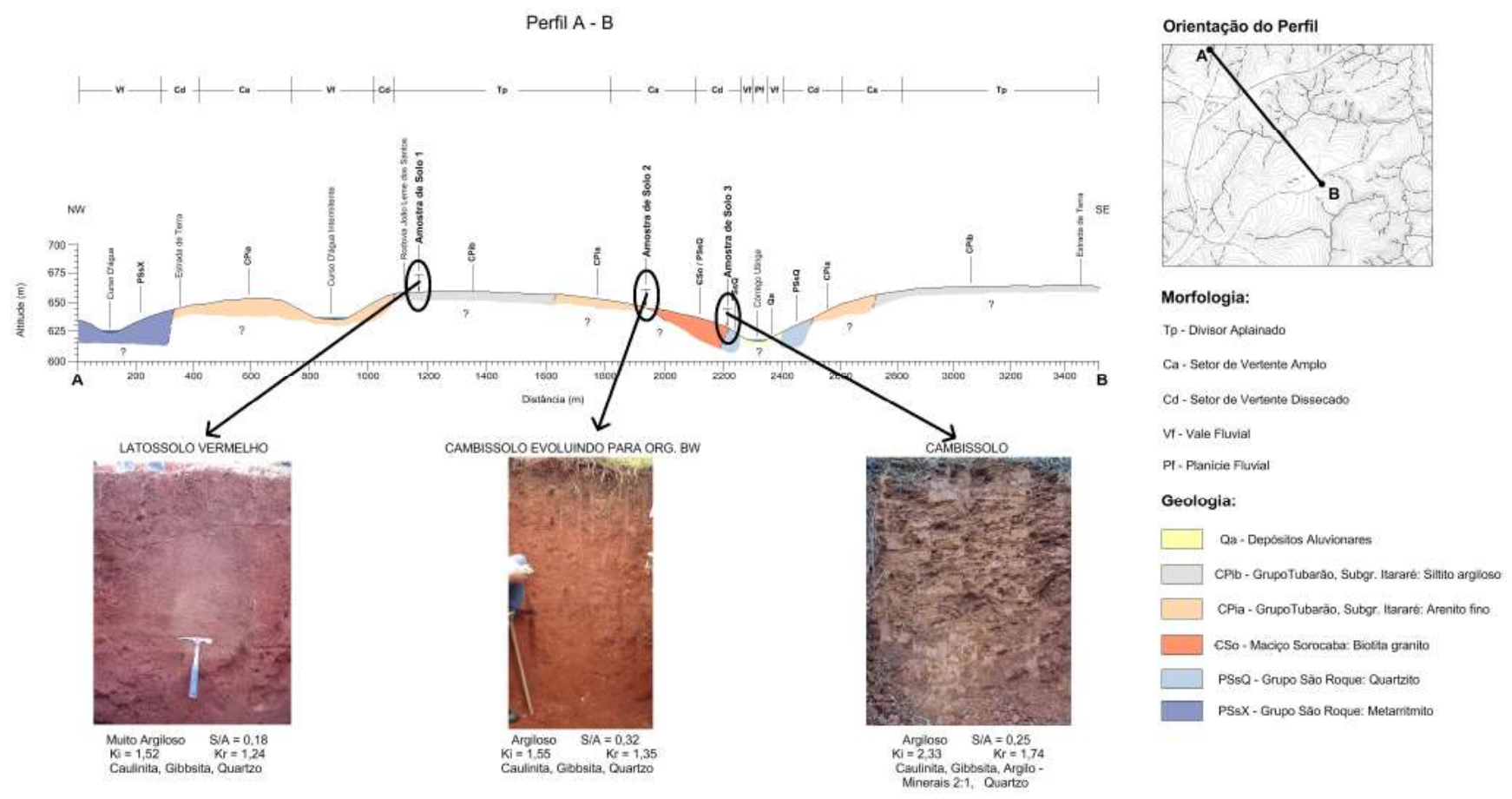

Figura 5 - Perfil A-B. Fonte: (IGC, 1979a,1979b, 1979c, 1979d). Elaborado pelos autores. 
Análise Geomorfopedológica na Borda Leste da Bacia Sedimentar do Paraná, Sudeste do Brasil

Perfil C - D

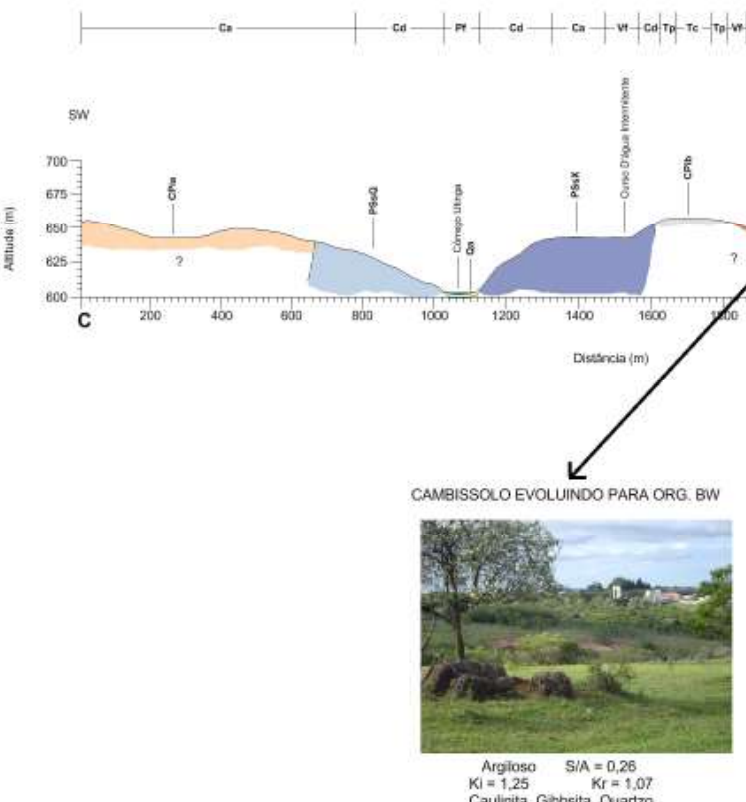

Orientaçăo do Perfil

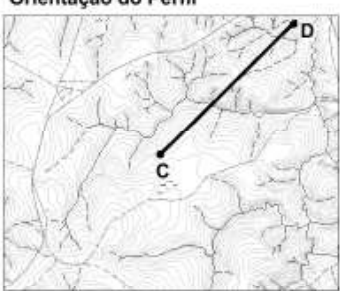

Morfologia:

Tc- Topo Convexo

Tp - Divisor Aplainado

Ca. Selor de Vertente Ampio

Cd - Setor de Vertente Dissecadio

V. Vale Fluvial

Pf - Planicie Fluvia

Geologia:

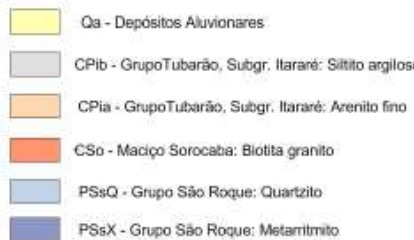

Figura 6 - Perfil C-D. Fonte: (IGC, 1979a,1979b, 1979c, 1979d). Elaborado pelos autores.

Perfil E - F

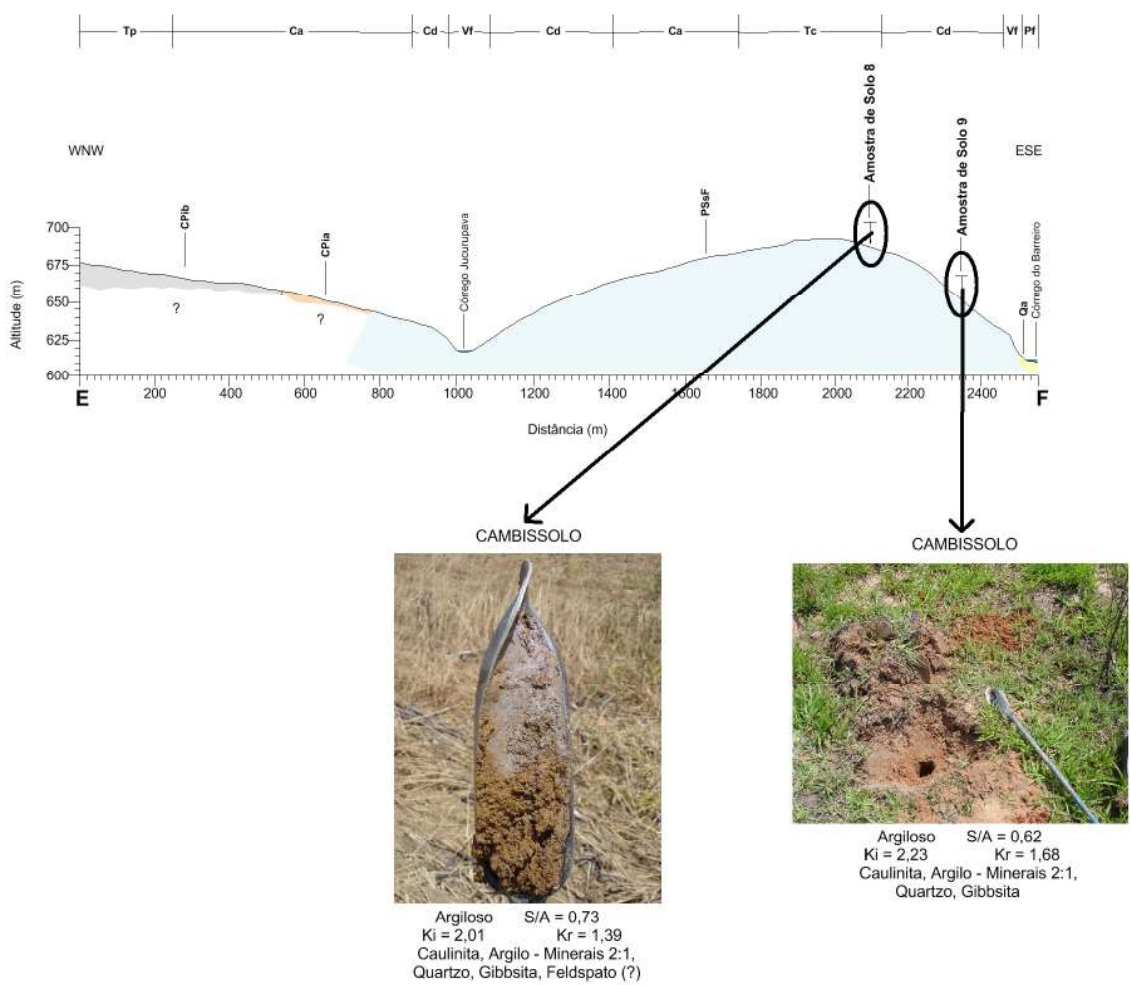

Orientação do Perfil

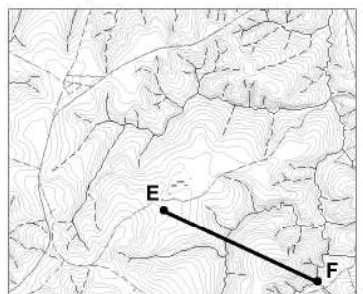

Morfologia:

Tc - Topo Convexo

Tp - Divisor Aplainado

Ca. Setor de Vertente Amplo

Cd - Setor de Vertente Dissecado

Vf - Vale Fluvial

Pf - Planicie Fluvial

Geologia:

Qa - Depósitos Aluvionare

CPib - GrupoTubarăo, Subgr. Itararé: Siltito argiloso CPia - GrupoTubarăo, Subgr. Itararé: Arenito fino

PSsF - Grupo São Roque: Filito

Figura 7 - Perfil E-F. Fonte: (IGC, 1979a,1979b, 1979c, 1979d). Elaborado pelos autores. 
Os Latossolos Vermelhos Bw têm seu desenvolvimento relacionado ao relevo mais aplainado, assim como os Cambissolos evoluindo para a formação de horizonte Bw. Em ambas as situações evidencia-se a atuação geoquímica sobre a superfície; no primeiro há pedogênese sobre a cobertura sedimentar e no segundo há alteração dos granitos, exumados nesse caso pela erosão mecânica. Estes enfrentam condições de hidrólise (monossialitização) e grau de intemperismo mais avançado sobre a cobertura pedológica, em comparação com os metassedimentos de pedogênese incipiente e morfologia com dissecação mais acentuada em razão da foliação existente.

Igualmente, a presença de uma depressão interfluvial na área dos divisores aplainados, em que foram constatadas condições de hidromorfia, indica haver processos de dissolução e rebaixamento do terreno, apontando ação geoquímica na escultura da superfície. As camadas sedimentares possuem menor espessura ( $\sim 30$ a $40 \mathrm{~m})$ e podem sofrer contato com os metassedimentos que apresentam corpos carbonáticos. A água pode percolar até o material carbonático e, auxiliada pela foliação, infiltrar pelo corpo rochoso dos metassedimentos, intensificando a segregação do ferro e da argila e criando condições para haver hidromorfia e aparecimento da forma depressionada localizada.

Dessa maneira, observa-se rebaixamento da superfície associada à erosão geoquímica, acompanhada pelo desenvolvimento dos solos por processos de dissolução e lixiviação. $O$ colapso das estruturas dos minerais representa também perda de volume no material alterado, pois permite o ingresso de fluídos nas estruturas cristalinas e o espessamento dos perfis de alteração, com consequente reflexo na morfologia do relevo. A ocorrência de argilo-minerais não requer necessariamente que esses tenham se formado concomitantemente à ação de intemperismo e rebaixamento do relevo, pois é possível haver tempos muito diferenciados nos processos que levaram a paisagem a conquistar sua morfologia atual.

Cabe apontar que, embora haja associação às superfícies de aplainamento estudadas por Büdel (1982) ou Millot $(1977,1983)$, notam-se processos diversos dos enunciados por esses autores. Büdel (1982) indica haver diferença de tempo entre os processos que levam ao aplainamento pelos mecanismos de formação das duplas superfícies, intuindo que a superfície de lavagem prepararia o ataque químico da superfície basal de intem- perismo subjacente para, assim, haver o rebaixamento de ambas. Contudo, isso não é comprovado na área de estudo, pois se verifica transformação da superfície que, enquanto passa pelas reações geoquímicas e erosões mecânicas, sofre rebaixamento.

Da mesma maneira, Millot $(1977,1983)$ verifica estados isovolumétricos na alteração dos materiais, havendo perda de volume apenas quando há desequilíbrio pedobioclimático e processos de pedogênese que implicam na alteração da declividade da vertente e no rebaixamento do modelado. Entretanto, isso não é verificado na área de estudo, já que se encontraram perfis alterados de granito em áreas de topos aplainados e setores de vertente amplos.

Assim, acredita-se não ser possível haver rebaixamento do relevo apenas quando há pedogênese e migração de matéria. É concebível que tal processo ocorra já quando há alterações geoquímicas na rocha matriz, no caso o granito, que, em sua massa, representa superfície fóssil exumada, atacada e suavizada geoquimicamente pela exposição direta à atmosfera.

\section{Considerações Finais}

A relação relevo-rocha-solo na área de pesquisa foi investigada por meio da geomorfopedologia, cuja metodologia norteou a investigação das combinações do relevo com os solos e consequentemente com a litologia. Caracterizações geomorfológicas e geomorfopedológicas levaram à percepção do controle litoestrutural, às associações entre os fatores investigados e à interpretação de que a superfície é rebaixada de maneira similar aos modelos de etchplanação.

O levantamento geomorfopedológico demonstrou que devido às condições de hidrólise mais avançada nas formas de relevo mais aplainadas, ocasionadas pela ocorrência de gibbsita e argilo-minerais como a caulinita, é possível notar a existência de processos de erosão geoquímica na formação da superfície. Da mesma forma, a predominância de processos de lixiviação e dissolução de minerais é concomitante às superfícies mais aplainadas, indicando haver rebaixamento da topografia. Além disso, a presença de uma depressão interfluvial na área de divisores aplainados, associada ao abatimento da superfície, implica em dissolução no topo da estratigrafia (siltitos argilosos) e igualmente em rebaixamento da topografia. 
A superfície aplainada da área de estudo pode ser, assim, um etchplano, correspondendo também a uma antiga superfície geomórfica recoberta por Latossolos em áreas de topo preservadas no decorrer do tempo geológico. Os Cambissolos, por sua vez, ocorrem em sua maioria nas vertentes sobre litologia cristalina, embora não se verifiquem declividades acentuadas e rupturas de declive marcantes. Tal condição pode estar associada ao controle da litoestrutura.

\section{Agradecimentos}

Os autores são gratos à Prof. ${ }^{a}$ Dra ${ }^{a}$. Lylian Coltrinari pelo apoio na cartografia geomorfológica e pelos valiosos apontamentos, e à especialista do Laboratório de Geomorfologia Dra. Marisa de Souto M. Fierz, ambas do Departamento de Geografia da Universidade de São Paulo. Agradece-se também à geóloga Letícia C. Vicente pelo apoio no levantamento e no mapeamento geológico. Igualmente importantes foram as sugestões do Prof. Dr. Adilson Avansi de Abreu, do Departamento de Geografia da Universidade de São Paulo; do Dr. Márcio Rossi, do Instituto Florestal do Estado de São Paulo; e da Dra. Lídia Keiko Tominaga, do Instituto Geológico do Estado de São Paulo. Além disso, agradece-se ao Dr. Marcos Roberto Pinheiro, especialista do Laboratório de Pedologia do Departamento de Geografia da USP, por seus apontamentos.

\section{Referências Bibliográficas}

AB'SÁBER, A. N. Participação das depressões periféricas e superfícies aplainadas na compartimentação do planalto brasileiro. Geomorfologia, São Paulo, n. 28, p. 1-38, 1972.

ALMEIDA, F. F. M.; HASUI, Y.; PONÇANO, W. L.; DANTAS, A. S. L; CARNEIRO, C. D. R.; MELO, M. S.; BISTRICHI, C. A. Mapa geológico do Estado de São Paulo. São Paulo: IPT, 1981. 1 mapa. Escala 1:500.000. Monografias 6. 2 v., n. 1184.

BÜDEL, J. Climatic geomorphology. New Jersey: Princeton University Press, 1982. 443p.

CASTRO, S. S.; SALOMÃO, F. X. T. Compartimentação morfopedológica e sua aplicação: considerações metodológicas. GEOUSP, São Paulo, n. 7, p. 27-37, 2000.

COLTRINARI, L. Contribuição à geomorfologia da região de Guaratinguetá-Aparecida. 1975. 156 f. Tese (Doutorado)Faculdade de Filosofia, Letras e Ciências Humanas, Universidade de São Paulo, São Paulo, 1975.
. Evolução geomorfológica do Planalto de São José dos Campos (SP). 2003. 114 f. Tese (Livre Docência)- Faculdade de Filosofia, Letras e Ciências Humanas, Universidade de São Paulo, São Paulo, 2003.

Paleosurfaces in southeastern Brazil: São José dos Campos plateau landform evolution. Geociências, São Paulo, v. 30, n.1, p. 113-120, 2011.

DE MARTONNE, E. Problemas morfológicos do Brasil Tropical Atlântico. Revista Brasileira de Geografia, São Paulo, ano 5, n. 4, p. 523-550, 1943.

Problemas morfológicos do Brasil Tropical Atlântico.

Revista Brasileira de Geografia, São Paulo, ano 6, n. 2, p. 155-178, 1944.

EMPRESABRASILEIRADEAGROPECUÁRIA-EMBRAPA. Sistema Brasileiro de Classificação de Solos. 2. ed. Rio de Janeiro: Centro Nacional de Pesquisa de Solos; EMBRAPASPI, 2009. 412 p.

FILIZOLA, H. F. O papel da erosão geoquímica na evolução do modelado da Bacia de Taubaté - SP. 1993. 114 f. Tese (Doutorado)- Faculdade de Filosofia, Letras e Ciências Humanas, Universidade de São Paulo, São Paulo, 1993.

GODOY, A. M. Caracterização faciológica, petrográfica e geoquímica dos maciços Sorocaba e São Francisco. 1989. 220 f. Tese (Doutorado) - Instituto de Geociências, Universidade de São Paulo, São Paulo, 1989.

INSTITUTO DE PESQUISAS TECNOLÓGICAS - IPT. Plano de Bacia da Unidade de Gerenciamento dos Recursos Hídricos do Sorocaba e Médio Tietê (UGRHI-10): relatório final. São Paulo: IPT, 2006. 153 p.

INSTITUTO GEOGRÁFICO E CARTOGRÁFICO - IGC. Folha Bairro do Arado - SF-23-Y-C-V-1-NO-E. São Paulo: IGC, 1979a. 1 mapa. Escala 1:10.000.

Folha Bairro Utinga: SF-23-Y-C-IV-2-NE-F. São Paulo: IGC, 1979b. 1 mapa. Escala 1:10.000.

Folha Fazenda São Marcos: SF-23-Y-C-IV-2-NE-D. São Paulo: IGC, 1979c. 1 mapa. Escala 1:10.000.

Folha Votorantim II: SF-23-Y-C-V-1-NO-C. São Paulo: IGC, 1979d. 1 mapa. Escala 1:10.000.

INSTITUTO NACIONAL DE METEOROLOGIA - INMET. Sistema Nacional de Informações Hidro-Meteorológicas SIM. Brasília: INMET, 2011. Disponível em: <http://www. inmet.gov.br/projetos/rede/pesquisa/form_mapas_mensal.php>. Acesso em: 4 abr. 2011. 
INTERNATIONAL SYMPOSIUM ON THE GONDWANA STRATIGRAPHY AND PALAEONTOLOGY, 1., 1987, Curitiba. Proceedings... Curitiba: Imprensa da Universidade Federal do Paraná, 1967. 344 p.

JUNDSONDAS POÇOS ARTESIANOS LTDA. Relatório de Ensaio No 25749/2012-1.0. Contrato 009651/12, Sorocaba: SAAE Sorocaba, 2012. 28 p.

KING, L. C. A geomorfologia do Brasil oriental. Revista Brasileira de Geografia, São Paulo, v. 18, n. 2, p. 147-265, 1956.

MILLOT, G. Géochemie de la surface et forms du relief présentation. Sci. Géol. Bull., Strasbourg, v. 30, n. 4, p. 229233, 1977.

Planation of Continents by Intertropical Weathering and Pedogenetic Processes. In: INTERNATIONAL SEMINAR ON LATERITISATION PROCESSES, 1983, São Paulo. Proceedings... São Paulo: IUGS, UNESCO, IGCP, IAGC, 1983. p. 53-63.

PÉREZ-VIEIRA, G. L. Análise e correlação de seqüências de $3^{\mathrm{a}}$ ordem do subgrupo Itararé $(\mathrm{PC})$, entre a região de Sorocaba-Itapetininga, SP, e a região ao sul do Arco de Ponta Grossa, Bacia do Paraná, Brasil. 2007. 217 f. Dissertação (Mestrado)- Instituto de Geociências, Universidade de São Paulo, São Paulo, 2007.

ROSS, J. L. S. Análise Empírica da Fragilidade dos Ambientes Naturais e Antropizados. Revista do Departamento de Geografia, São Paulo, n. 8, p. 63-74, 1994.

Geomorfologia, ambiente e planejamento. São Paulo: Contexto, 1991.85 p.

. O registro cartográfico dos fatos geomórficos e a questão da taxonomia do relevo. Revista do Departamento de Geografia, São Paulo, n. 6, p.17-28, 1992.

ROSS, J. L. S.; MOROZ, I.C. Mapa geomorfológico do Estado de São Paulo. São Paulo: DG/FFLCH/USP, IPT, Fapesp, 1997. 2 mapas. Escala 1:500.000. 2 v.

SANTOS, R. D.; LEMOS, R. C.; SANTOS, H. G.; KER, J. C.; ANJOS, L.H. Manual de descrição e coleta de solos no campo. 5. ed. Viçosa, MG: Sociedade Brasileira de Ciência do Solo, 2005. 100p.

SHUTTLE RADAR TOPOGRAPHY MISSION - SRTM. South
America Images. NASA, 2000. Disponível em: $<$ http://www2. jpl.nasa.gov/srtm/southAmerica.htm>. Acesso em: 3 jul. 2009.

SILVA, P. C. F. Ambientes de sedimentação e tectônica do Grupo São Roque na região entre Pilar do Sul e Votorantim, SP. 1997. 127 f. Dissertação (Mestrado)- Instituto de Geociências, Universidade de São Paulo, São Paulo, 1997.

THOMAS. M. F. Geomorphology in the tropics: a study of weathering and denudation in low latitudes. Chichester: John Wiley \& Sons, 1994a. 460 p.

. Ages and geomorphic relationships of saprolite mantles. In: ROBINSON, D. A.; WILLIAMS, R. B. G. Rock weathering and landform evolution. Chichester: John Wiley \& Sons, 1994b. p. 287-301.

Tropical geomorphology: a study of weathering and landform development in warm climates. London: The Macmillan Press Ltd, 1979. 332 p.

TRICART, J.; KILIAN, J. La eco-geografia y la ordenación del medio natural. Barcelona: Anagrama, 1979. 288 p.

VILLELA, F. N. J. Análise da relação relevo-rocha-solo no contato Planalto Atlântico - Depressão Periférica Paulista. 2011. 257 f. Tese (Doutorado)- Faculdade de Filosofia, Letras e Ciências Humanas, Universidade de São Paulo, São Paulo, 2011.

VILLELA, F. N. J.; ROSS, J. L. S.; MANFREDINI, S. Reliefrock-soil relationship in the transition of Atlantic Plateau to Peripheral Depression, São Paulo, Brazil. Journal of Maps, Oxford, v. 9, n. 3, p. 343-352, 2013. Disponível em: <http:// www.tandfonline.com/doi/abs/10.1080/17445647.2013.80517 0\#.U78KnJRdV8F>. Acesso em: 10 jul. 2014.

VITTE, A. C. Etchplanação em Juquiá (SP): relações entre o intemperismo químico e as mudanças climáticas no desenvolvimento das formas de relevo em margem cratônica passiva. 1998. 276 f. Tese (Doutorado)- Faculdade de Filosofia, Letras e Ciências Humanas, Universidade de São Paulo, São Paulo, 1998.

WAMBEKE, A. V. Soils of the tropics: properties and appraisal. New York: McGraw Hill, 1992. 291 p.

WAYLAND, E. J. Peneplains and some other erosional platforms. In: ADAMS, G. F. Planation surfaces: peneplains, pediplains, and etchplains. Chichester: John Wiley \& Sons, 1933. p. 354-357. (Benchmark Papers in Geology, v. 22). 